\title{
Status of Women in Uzbekistan
}

\author{
Saima Ibrahim \\ Centre of Central Asian Studies, University of Kashmir, India
}

\begin{abstract}
Women as an individual or as an autonomous political being are treated unequally and unjustly by every society. Her basic and fundamental rights are being violated since centuries and in all the societies and Uzbekistan is not an exception. Uzbekistan is a patriarchal society in which a cultural bias against women has been an acceptable fact. After the disintegration of the Soviet Union, Uzbekistan opened a new chapter to bring socio-cultural changes in the status of women. Uzbekistan inscribed gender equality in the constitution. Women have been guaranteed equality of rights by the law but are unable to get equality by male dominated society and family. The objective of this paper is to highlight the status of Uzbek women in different periods with special reference to status of women in independent Uzbekistan.
\end{abstract}

Keywords- Women, Soviet Union, Status, Uzbek, Gender

\section{INTRODUCTION}

The question of Women's Rights has attained paramount significance throughout the course of history almost among all the civilized communities of the world. The reason is obvious, for thousands of years women were kept in total subjugation as most of the societies were patriarchal. For centuries it was considered a natural law that women were inferior to men and therefore were to submit to the latter's authority for the smooth functioning of the family life. The doleful condition of women has been even woven in the historical layers. Historically speaking, there has been male domination in almost all societies throughout the ages. Man was to possess and dominate women, have mastery over her and determine her future, in the capacity of a father, brother or a husband. Confined to home and hearth, she was deemed incapable of taking decisions outside her domain. [1]

The path covered by the Republic of Uzbekistan in the years since it acquired independence highlights the difficult situations faced by the new Central Asian states. The republic is characterised by a combination of economic transformation and strengthening of authoritarian government. During the past 20 years of independence, Uzbekistan has moved along a path of gradual development of democracy, socially oriented market economy, the nation building process by keeping the indigenous ethno- national culture and traditions as the core of the independent state of Uzbekistan. Whereas we find traditionalism and modernity co-existing in Uzbekistan, [2] traditionalists wanted women to remain at home, the liberals wanted to promote women's equality and their participation in the society on equal footing with men. Uzbekistan is on the path of national revivalism, it is reviving the past in which women were believed to be inferior as compared to men. They were simply meant for the household and family affairs, including the upbringing of children. The status of women folk in modern Uzbekistan is largely related to the past. The country has inherited the Soviet legacy combining both indifference and softness towards the women in the overall gender structure. In sequence thereof, the socioeconomic status of the womenfolk including their public life is getting affected. [3]

\section{PRe-Soviet Period}

Women's position in the history of Central Asian region, the former colonial periphery of imperial Russia, was mostly determined by "the strict traditions and canons of Islam". [4] In the past, western writers visiting Central Asia generally presented a gloomy picture of its society especially of women who according to them were totally subjugated by their men-folk and religious leaders, treated as chattels, forced into hellish marriages and leading lives of virtual slavery. [5] The Soviet sources with their colonial ideology portrayed the negative image of traditional culture. The lack of gross understanding of Central Asian family structure inclined them to look upon the women folk of Turkistan nothing more than slaves, subject to whims and wishes of their lords and masters. During the pre-Soviet period, marriages were arranged by close relatives in accordance with the rules of Islamic and customary law; neither the bride nor generally the bridegroom had any say in the choice of their future partner. There was frequently a considerable difference in age between husband and wife, since the financial obligations incurred by the male were very heavy, especially the payment of the bride-price (Kalym); only young men from the wealthiest families could afford this. [6] The price depended on the wealth and standing of the groom. In lieu bride would bring dowry with her which would often take the form of linen and household goods. Although polygamy is legal in Muslim law and men are permitted to have four wives at a 
time (on condition that all were treated equally) but in practice only the rich have more than two. [7] Similarly under Muslim law, a man can divorce his wife at will but at the same time he has to return all her property, pay the Kalym in case it is not already paid. Apparently this practice of Kalym appears as a sort of enslavement and debasement of women but at the same time it acted as a check to divorce as well. The value of bride-price and dowry made divorce an expensive luxury which everyone could not afford. [8] Also among crafts men and rural cultivators where women made a substantial contribution to the family economy, divorce would be extremely expensive. Moreover it is not only man, a woman too can compel her husband to divorce her on certain grounds, (END) one, if the husband is absent for certain time without any news being heard of him, two, if a wife is a minor she can refuse to continue the marriage until she attains majority, three, if she can prove that he is treating her badly or he has married a second wife without her formal permission. Although women are subservient to their husbands at the same time they have certain rights as well. She has a right to food, clothing, lodging servants, money, and to all those expenses which are usual among persons of her rank. If these were not provided by the husband she can complain to the Qazi or judge who can allow her to borrow money on account of her husband, or can even order the sale of some portion of her husband's property in order to provide her money which is necessary. [9] Traditionally women did not share in the parental estate. After marriage, the next great increase in status, rights and respect for the women comes from bearing the son. Her position becomes far more secure and stable. With the birth of a son, the mother gains property rights as well: if she is widowed, she acts as guardian of her son's portion while he is a minor. [10] Further instance of the increased status may be found in the levirate. [11] In a sense the levirate is a form of social insurance; thus the widow will be taken care of. The above facts shows a sort of discrepancy in the statements of Western scholars when they represent the picture of Central Asian women worst than a slave. The basis of their understanding of the issue is based on their limited understanding of the marriage system like bride- price or Kalym, polygamy, child marriage and paranja system in vogue in Central Asian society. They have neglected the magnificent and influential role of Muslim women in the court politics and the ability of middle class women to maintain control over the whole family through their industry even in the presence of patriarchal family structure. Women played an important role in the socio-economic field and provided a substantial financial support to their families. [12] Not only this, even wives of high officials made crafts at home which they sent to the market for sale to have some income of their own.[13] There have been cases where a wife has supported the whole family by selling her embroidery and hatching silkworm eggs. This hatching industry remained entirely in the hands of women. Some women are metal workers and make bowl and so on, other embroidered caps for sale in bazaar. [14] Central Asia had a long tradition of female teachers known as Otines who were responsible for the religious education of both boys and girls in their own homes. [15]These were invited by the families to participate in the rituals such as birth, marriages etc. These Otines also recited prayers or mystical poems at various religious ceremonies among women such as Mavlud (commemoration of the Prophet Mohammad SAW's birth). Education in this period was founded on Islamic learning and among women was confined exclusively to those from the wealthy strata of society. In fact Otines were honorific titles and referred to the educated ladies, especially ladies of the court. [16]

In the late $19^{\text {th }}$ century and early $20^{\text {th }}$ centuries, long before the Bolshevik group, a progressive movement of the national intelligentsia known as Jadidism had raised the issue of drawing women into social and cultural life as part of its programme to revitalize and reorganize society. Shura-i-Islam, a Jadidist organisation, was the first to make the issue of women's participation in elections a part of its programme. They believed that society's intellectual level depended in many respects on the status of women. They held that society's transformation must begin with reforms in the spiritual and cultural spheres and in everyday life, which also meant changing the perception of women's place and role in Muslim life. [17] Jadidism advocated equality and secular education for women and condemned polygamy and the poor treatment of women. They realized that the progress and civilization of a nation is depended upon the educational, moral and intellectual progress and civilization of women because of the crucial role of women as mothers of the next generation. [18]

\section{SOVIET PERIOD}

Since the beginning of the Soviet period, soviet leaders have been committed to the ideal of women's liberation in all regions of their country to the ideal of placing women on an equal footing with men in all aspects of economic, social and political life. [19] They intended to designate women as a producer of new social order. In order to achieve this objective, they first considered it necessary to eliminate the so called oppression of Muslim women inherited from native khans and tsars by favouring her with so called socioeconomic liberation, not with any philanthropic motive but with the intention of increasing the labour force for assuring the success of drive for cotton and fostering the creation of a socialist economy. Secondly, to Russian eyes, the treatment of Central Asian women in traditional society seemed equivalent to slavery and thirdly the Communist party aimed to suppress Islam. [20] This transformation was to pave the way for the introduction of Communism which was not possible without the participation of women. Bolsheviks were bent upon 
transforming the position of Muslim women since they were convinced that women have assumed the role of guardians of the faith which they wanted to eradicate by implementing a massive propaganda machine that continued till the period of perestroika.

To achieve their motive the Soviet policy towards women was implemented in two steps. The first step to be taken was the secularisation of family law. A new set of codes and civil tribunals replaced the traditional and Shariah based tribunals which had previously regulated life. [21] In 1918, the official registration of marriages, births and deaths was made compulsory while religious marriages (nikah) were banned. Instead of Shariah code, Soviet divorce law was introduced, to give women greater protection. Between 1921 and 1923, laws were passed banning such practices as polygamy, the payment of Kalym (bride-price) and marriage without the consent of the bride, while the legal age for marriage was fixed at sixteen years (instead of nine) for girls and eighteen years (instead of sixteen) for boys. Women were given the right to vote and access to all positions of power (Article 64 of the Soviet constitution of 1918). Great efforts were made to publicise these new legal provisions. The laws were translated into local languages and the texts disseminated widely. Public meetings and rallies were held to explain women's civil and constitutional rights. Several were given basic training in Soviet law and attached to the courts of People's Assessors. Later, longer courses were provided and towards the end of the 1930's they began to enter judiciary. [22] Another aspect that was the result of hard work of years, was the training of local cadres. The first activists were almost all young Russian Communists; [23] few of them had any knowledge of the local languages or customs. Gradually, however, from about 1925 onwards, they were joined by local supporters. They were mostly young girls from poor backgrounds who, for one reason or another had become actively involved in the emancipation movement. By 1920, a number of women's groups (Zhenotdels) of the communist party had been organized in Central Asia. The Zhenotdels organized women activists to go from house to house and to start women's social clubs, cooperatives, shops and special places where women learned to sew, read and write without encountering men. Persuasion was the primary method in the work of the Zhenotdels. [24]Here they were able to provide a secluded, protected environment in which women could feel at ease outside their own homes. One of the most important areas of the work of the women's groups was organization of social clubs exclusively for women. The first such club was established in the old quarter of Tashkent in 1924. [25] These clubs explained and made women aware of their legal rights under the new Soviet government. Later the clubs directed their efforts towards the cultural up-liftment of women. These included removal of illiteracy, training in various modern ways of life, medical aid, educational advice, theatrical performances, consultations on nutrition, hygiene and child care and also lectures, film shows and concerts. Finally, the clubs began to give emphasis upon the women's participation in social production by raising their skill level. The clubs organized in many districts women's training courses for various kinds of factory work and trades. Even workshops and trade schools were set up by the clubs for this purpose. They represented the first tentative step towards women's full participation in public life. [26]

The second step known as a campaign of emancipation called Hujum (offensive) was launched simultaneously against traditional life styles, cloistering of women, the heritage of slavery etc. The first largescale displays of unveiling took place in 1927, on International Women's Day $\left(8^{\text {th }}\right.$ March), a historic day in the life of Uzbek women. On that day thousands of women marched through the streets, squares and bazaars of Central Asian cities like Tashkent, Samarkand, Bukhara, Kokand etc had cast off their parandzha (traditional garb which cover the body entirely) and Chachvan ( a woven screen covering the face) and ceremonially incinerated them on giant bonfires. The wearing of the veil was not banned by law (although some activists were in favour of this), but a variety of so called 'administrative' measures were used to further the campaign. Special privileges were given to women who discarded the veil and such women who continued with the practice, their husbands were liable to penalty. [27] On occasion, more ruthless methods were used; women were intimidated into unveiling, or unveiled by force. However, in country areas or in the old quarters of the cities, women continued to cover their heads and shoulders with large head-scarves. [28] Outside the home, any unveiled woman was assumed to be equivalent of a prostitute. More than a thousand unveiled women were murdered, either by their relatives or by the basmachi (local guerrilla movements) in these years. In Uzbekistan alone 203 Uzbek women were killed for abanding the veil in 1928 and another 165 in the first half of 1929. The year 1932 marked the beginning of a new era for Central Asian women educated and trained by the Communist party. These female Communist workers were sent to Moscow to oversee the political education whereby they were supposed to exercise culture and so called civilizing influence on the indigenous women. The Soviet authorities regarded education as an essential component of political and economic mobilisation. Special ABC courses (likbez) courses were set up in railway coaches, tents, factories and every conceivable venue. Primary education was made compulsory for boys and girls alike by about 1930s. Special attention was being given to eliminate illiteracy among women. In a number of towns special women's schools of a higher type were organized. Thereafter, women enter the professions, particularly law, medicine, teaching and scientific research. [29] School was not only the place where a general educational programme was provided; it was also the channel through which the values and goals of communism could be incalculated in the younger 
generation. The educational process was also used to challenge inherited conventions regarding the role of women in society. [30]

During the same period, energetic efforts were made to involve women in the political-administrative process. Female delegates were elected to represent their communities in public meetings at local and republican level. [31] Although their participation remained low, but actual numbers were quite high, given their lack of previous political experience; in Uzbekistan for example, by the beginning of 1929 there were over 1000 Uzbek women party members. Positive discrimination was used to accelerate promotion and a quota system was introduced whereby women were allocated approximately a third of the posts in government and in party administrative organs. [32]The first step to draw women into socialised labour was made through women's cooperatives. Special shops and consumer cooperatives were set up through which women could sell their products directly. Towards the end of the decade there was a proliferation of light industrial enterprises and increasing numbers of local women found work in factories concerned with food processing, silk-spinning and the production of garments and hosiery. [33] Heavy industry was developed somewhat later, but relatively few female workers were employed in this sector since conditions were considered to be unsuitable for women for physical as well as psychological reasons. [34] During Soviet period, land and water reforms were introduced, which enforced the principle of equal rights for men and women and gave women economic independence.

\section{POST-SOVIET}

The Post-Soviet period set the scene for major political and economic changes in Central Asia with the rise of five independent states in the region leading to a drastic revision of previous ideologies. The revival of indigenous cultural values represented by Islam has become one of the political catchwords of the newly independent states. As a result, the equality between men and women which was strongly associated with Soviet ideology became the target of strong criticism with the activation of religious and national consciousness. A clear trend towards a change in the social system emerged during the transition period. Despite the fact that the principle of equality continues to feature in the constitutions of the Central Asian Republics, state authorities support a new patriarchal order based on the traditional role of women as mothers. [35] The Constitution of Uzbekistan prohibits all forms of discrimination and provides for identical rights for men and women. There are however special provisions that pertains only to women in various codes such as family code adopted in 1998 and labour code. These conditions set privileges and protective measures proceeding from women's biological and reproductive function. After the disintegration of Soviet union, Uzbekistan opened a new chapter to bring socio-cultural changes in the status of women. Although socio-cultural changes took place in independent Uzbekistan, such changes witnessed the decline of women's position in the society.

\section{SOCIAL STATUS}

In Post -Soviet times, a reversal to traditional values, first and foremost, has greatly affected women. A family has always been one of the custodians of traditional culture and in order to understand the true status of women in society, it is necessary to look at how women feel about her role within family, traditionally regarded as the sphere of women realisation. In contemporary Central Asia, particularly in Uzbekistan, women occupy secondary status in the society. Society with its rigid structures still continues to be patriarchal and sexist. In such a patriarchal society men behaves aggressively and dominate over women and, as a result, women never experience justice. In Uzbekistan there is high level of marriage but low level of divorce. So a girl in Uzbek society is a victim of double oppression both in the hands of law and in the hands of her husband. [36] Early marriage is another feature of Uzbek society. It has resulted in incomplete education of women, bigger families with more children and restrictions on the welfare of women [37]. Although as per the law the minimum age for the marriage of girls is 17 and 18 for boys, under special circumstance and with the permission from the hokim (head of local administration), the age may be reduced though not by more than one year for if there are valid reasons or exceptional circumstances (article 15 of family code). [38] Parents support early marriage because it relieves moral, societal pressure on them to take responsibility for the future of their children. The majority of parents also consider early marriage more preferable because it follows the logic of traditional society, ensuring greater acceptability of the traditional norms. This traditional logic is applied to women for earlier marriages e.g in 1991, 42.7\% of girls under 19 years old in Uzbekistan were married. This number grew by $9 \%$ by 1994 when it constituted 49.7\%. [39]. In social sphere, arranged marriage still continues to be the norm. With the system of bride price continuing to be in vogue, many parents prefer to give their daughters in marriage to close relatives rather than lose their wealth to another clan. [40] Uzbek government in order to curb the polygamy ordered that all marriages were to be registered yet it is not easy to eliminate the age old custom. The men went for polygamy by not registering the other marriage. Such marriages especially the second marriages are solemnised through a Muslim ceremony(nikah) devoid of any legal status . [41] Women who are second wives often face difficulties concerning property and child custody if they leave their husbands. So defacto polygamy continues and remains socially acceptable. Divorce in Uzbekistan is not difficult especially if the application was made 
with the mutual consent of both spouses. However at the same time there were some legal provisions which aimed to protect women in these situations. e.g a husband can not divorce his wife if she is pregnant or if they had a child under one year of age( article 39 of family code). The rate of divorce in Uzbekistan is half than that of the Russian Federation because of the strong influence of traditional social norms regarding women which required them to remain submissive and not to create circumstances which could lead to divorce. As a result many women who have valid grounds for divorce do not exercise their legal right to divorce for fear that their parents and relatives would hold them responsible for the breakdown of marriage. Instead they tolerate domestic violence, polygamy and humiliation for the sake of preserving the family unit and for the sake of their children. [42] Other factors include economic hardships, rise in expenditure of kalym and lavishness in the ceremonies of marriages are the reasons that do not encourage divorce as its figures in 1990 were 30000 and in 1995 this figure falls to 21200. [43] The Uzbek Government has taken no significant steps since Independence to combat domestic violence beyond formal declaration on the status of women in Uzbekistan. There are no specific laws prohibiting domestic violence, to be treated like other crimes. Uzbekistan's first report to the Committee in the Elimination of All Forms of Discrimination against Women considered by the Committee in January 2001 provides only vague information on domestic violence. There is practically no public discussion in the media or otherwise on violence against women including domestic abuse by husband or in -laws. In Uzbekistan domestic violence has a quasi legal status. The facts of domestic violence are either hidden or discussed as isolated cases. Uzbekistan's traditional marriage and family structure is a strong influence on the prevalence and treatment of domestic violence Uzbek women brought up to be patient and obedient accept domestic violence as an integral element of family and think beating as the norm. For them it is a structural part of the overarching patriarchal legacy supported by countless tenacious traditions and customs. Women turn to the legal system only in extreme cases. They did not talk about violence for a variety of reasons. They feel ashamed or embraced about their situation or concerned about their repercussions to themselves and their families of exposing violence. A woman may be ostracized by family and by society for revealing abuse. At the same time, breaking up the family by using the legal system is strongly discouraged by both society and members of the legal system. The mahalla may perform a useful informal function as mediator of conflicts. Their mediation enjoyed a high success rate, but the success of mahalla efforts depend primarily on moral persuasion. Mahalla leaders frequently counsel victims of abuse to endure or change their own behaviour in order to make reconciliation possible. Mahalla fail to address the real harm being done to the victims of domestic violence, and do not act on the principle that domestic violence is a criminal offense. They interpret "reconciliation" of family conflicts as the cessation of complaints, rather than an end to the violence. Their intervention therefore is often directed toward placating the abuser, rather than helping the victim. [44]

\section{Economy}

The dislocation of supplies, services and trade which followed the collapse of Soviet Union has laid a devastating effect on the newly emergent national economies of Central Asian States. Prices for industrial and domestic commodities continue to soar; transport networks have been decimated owing to fuel shortages. Many industrial plants have been forced to close down, or to introduce sweeping redundancies, because of lack of supplies, loss of markets and huge debts. Unemployment has spiralled, education and medical care have been severely affected; standards have fallen dramatically, while the introduction of 'hidden charges' to services that were formerly free has further reduced the scope of welfare provision. [45] After independence, women have been the chief victims of shrinking labour markets. In the 1990-91, out of 10000 unemployed, $80 \%$ constituted women. According to employment exchange statics, 1991-94 the 70\% staff cutbacks that have taken place in organization (over the last four years) have been at the expense of women [46] and the trend continued as in 2000 women accounted about $63 \%$ of unemployed persons. [47] It is not only the unskilled or semi-skilled workers who have been savagely hit by redundancies but also the trained professionals. The quota system and the positive discrimination that operated in support of female employment during the soviet period have been abandoned. Now whenever there a choice between employing a male or a female, the former is automatically given precedence, on the ground that he is the main breadwinner in the family. [48]

During soviet period, wages in the education and health sectors were maintain close to the national average wage. After the collapse of Soviet Union, the relative level of wages in these sectors began to fall because of limited resources. In 1997, the average monthly wage was 3,681 sums. However, in the sectors with considerable female employment the average monthly wage was lower than the average national level .For example in the heath care and social security branch, the average monthly wage was $61 \%$ of national average (in some cases even $58.4 \%$ ). In education, the average wage was $67 \%$ of national average wage and $43.1 \%$ in preschool educational facilities. [49] After Soviet disintegration, Uzbekistan maintain a command economy through subsides and tight control on production and prices. This resulted in high inflation rate which forced the government to introduce the reforms policies in 1994. Uzbekistan is experiencing a rapid development of private sector and denationalization of many factories and plants. Although the privatization process has opened 
new opportunities for men who occupied previously high administrative positions, it has presented challenges for women. Women were badly affected by the privatization process, lack of skills; new forms of commercialization and growth of sex industry have all worked against the interest of women. Due to privatization process, women faced economic loss because privatization and structural adjustment programmes of IMF and World Bank have drastically cut the social outlays. [65] Women are being sacked in private companies. So they are deprived of employment benefits including child benefits and maternity leave of the government jobs. Today, they are engaged in most of the unorganized sectors and gender related areas where they are subjected to further exploitation, degradation of family values and societal cohesion. [66]

Furthermore, the disintegration of economy in post Soviet period forced people to flush out new forms of work. In the economic destabilization, a positive attitude to traditional craft work was a logical exit from the crisis. Women's choice to re-engage in craft work was supported by the government. The revival of cultural traditions in general encouraged the revival of traditional crafts. The Government's support of handicrafts strengthened the position of women. In Uzbekistan, there are quite a number of women's organizations supporting handicraft work e.g. Association of Business Women of Uzbekistan (BWA) is one of the first NGO in Uzbekistan which was founded in 1991. It started providing vocational education towards women entrepreneurs, taught the basics of market economy, marketing, accounting and taxation. They have taught more than 300 women to do gold embroidery, carpet weaving, chain stitch and hand embroidery and basket weaving. In cooperation with representatives of German Trade Palace, the association offers courses in techniques of carpet weaving and gold embroidery in several Uzbek provinces. The association's main goal is to help women survive and achieve economic independence in unstable economic conditions. The centre for handicrafts; Khamsa (Tashkent) has offered a great deal of support to crafts women. Besides, international organizations like UNESCO, SDC, CADA, CAMP etc offer enormous aid to women wishing to work in craft production. Jewellery making and gold embroidery has almost entirely passed into female hands. With the support of Association of Business Women of Uzbekistan and Jewellery school in Hanau (Germany), a jewellery school for young girls was established in Tashkent. This process is supported by government, international organization's and women's organizations that are dedicated to help women adapt to new economic realities. The main tasks of this movement are to increase the income and social status of women and to revive traditional crafts. [52]

As the majority of population lives in rural areas, land continues to represent one of the main productive resources in the country. Women's right to land and property in Uzbekistan is closely related to women's status in the family. Women usually are not given land shares as women never inherit land from their fathers. Although legally women have equal rights as men to possess land but stereotypes of public opinion condemn women who demand their rights. [53]

\section{Politics}

Uzbekistan has introduced a number of legislative changes and legal reforms designed to guarantee the interests and status of women. President Islam Karimov declared 1999, the Year of women saying, the way society treats women shows the level of the culture and the spirituality of a given society and the results of society's movement toward democracy.

This move was designed to draw attention to gender related issues that adversely affects women's ability to participate in society. [54] It was in the same spirit that President added by saying that 'our Government stresses the importance of women's participation and encourages their appointment to leading positions in lower, middle, and topmost administrative bodies. Women's involvement in government is one of the major elements in the construction of a democratic state. In joining UN, Uzbekistan has adopted many international agreements and conventions that confirmed women's rights and set the terms of the state's action plan for their protection. Participating in government, women can more efficiently and effectively gain true equality in all spheres of life. [55] But the fact being that women representation is low as they are mainly involved in local or grass root politics although they do hold some leading positions in political parties. There were only 17 women members of the parliament elected in November 1999 (compared with 23 in the previous elections) out of a total of 250 deputies. From 1008 persons nominated as parliamentary candidates 300 were women. [56] The decree of the president of the Uzbekistan entitled, Measures for increasing the role of women in the State and Society Construction of the Republic of Uzbekistan on $28^{\text {th }}$ November 1995 by which the new position of the female deputy Prime minister of the republic was established. This position was promoted to consolidate the position of women's committee by increasing their involvement in the resolution of social and cultural development and their participation in administration. [57] In 1991 the Women's Committee was established. It is the main institute responsible for the formulation and implementation of government policies relating to women's issues in the country. There is a structure of local self governance incorporating so called women's councils which are headed by women. [58] Similar positions at the deputy Hokim (deputy governor or deputy mayor) level were concurrently established for women at three administrative levels, provisional (oblast), and regional (rayon) and city levels. [59] The small number of women in managerial positions within 
the cabinet of ministers prevents them from having any real influence on decision making processes or in taking an active part in the implementation of these processes. The government is trying to increase the number of women involved in governmental structures but their number remains low and those women holding positions in governmental bodies have little work experience. Women have practically no role in decision making and policy making and this is partly because Uzbek women who even after achieving higher education qualifications prefer to raise a family rather than to start a career. Only in rare cases women become involved in politics. All women now working in governmental structures and local administration have a komosol and communist background whose careers date back to soviet times. [60]

Women account for 35\% of members in the Supreme Soviet of Uzbek SSR. By contrast they accounted for only 7\% of parliamentarians in the Oily Majlis in 2000 (i.e. 17 out of 250) members. The same decline is observed at local government levels. Where the proportion of women in the highest administrative and management positions such as deputy ministers and deputy directors of enterprises is 17.5.But the number of women elected to the national parliament, the Oily Majlis has recently increased from $9 \%$ to $18 \%$ since the December 2004 elections. This was largely due to the reintroduction of a quota system, not for the share of women parliamentarians, but for political parties that put forward candidates for elections, which were obliged to ensure that $30 \%$ of their candidates were women.

The growth of women's NGO is one of the most positive achievements in terms of women's political participation, in Uzbekistan. The primary foci of women's NGO in Uzbekistan are improvement of women's status in the family and society, protection of women and of women's legal rights and expanding women's access to new income and business opportunities. The Women's Resource Centre was organized by a group of women at different professions in 1995. The organization aims at strengthening women's independence and their spiritual, intellectual and professional potential. It also encourages women's active attention to the realities of social life and supports initiatives to broaden and deepen women's awareness of their role in social, economic and political life and of their rights and opportunities to attain genuine equality in all spheres of life. Similarly the women's society (merci) deals with the educational programs, reproductive health and legal literacy. [61]Over the past decade the NGO's have been active through seminars and training programmes, in educating legal professionals. They have also been active in conducting legal literacy programmes that train rural residents at community levels in the principles of gender equality setting up hot lines and providing free legal aid to the neediest. However such work has been neither systematic nor coordinated. It has been largely limited in scope and outreach. [62] Women by and large remain under represented in top political positions due to number of factors like the stereotypes and patriarchal norms existing in the society that limit the role of women to being housewife and mother and also there is a lack of leadership training for women. Women are not sufficiently aware of their rights. Women's NGO's are not protected by the government legally as well as materially. Patriarchal norms together with the overall governmental policy of control and limitations towards NGO's seriously hamper the participation of women in NGO's.

\section{Education}

After disintegration of Soviet Union, Uzbekistan faced economic crisis and women become the major victim in the process of educational development. Due to reduction of funds many schools were closed, which had a potentially negative impact on the preparedness of the children. Due to an increase in paid services in secondary and tertiary education, access to compulsory and higher education has declined sharply. Even teachers are leaving their profession due to poor working conditions and reduction of salaries, coupled with uncertainty of payment. [63] In 2007-2008, the percentage of boys and girls studying at schools is almost equal; $51 \%$ of boys and $49 \%$ of girls. [64] However women's participation in higher education has fallen since independence, due to a combination of factors, such as increasing cost of education and a reluctance of parents to allow their daughters to study in urban areas. Since the girls traditionally marry in their late teens or early 20's chances of their participation in higher education are minimized. [65] Besides Uzbek women are inspired to enrich and extend the knowledge concerning home life such as good manners, breeding proper family relationships as well as habits. Thus we can say that the educational status of women in Uzbekistan is neglected.

\section{Conclusion}

Uzbek woman might have won formal rights statutorily but in practice, the traditional society continues to hamper their progress. Women are also affected more disproportionately than men by the negative aspects of the on-going socio-economic transformation in Uzbekistan. Factors like increasing poverty, rising unemployment, lack of resources in many families to educate boys and girls, political marginalisation, domestic violence etc are compounded by the fact that the women are subjugated and exploited on all fronts in the male dominated society in which women have been granted equal rights not by the society but by the government decree. Efforts to educate the women about their rights, status and duties by government, NGOs and other organizations of civil society are too meagre in outreach and efficacy to produce significant results. In order to 
do away with the gender bias and discrimination all such rights that are guaranteed to women in Uzbekistan need to be implemented to ensure the equitable developments of sexes.

\section{REFERENCES}

[1]. Engineer, Asghar Ali, Rights of Women in Islam, Sterling Publishers Private Ltd. New Delhi, p.1

[2]. Mushtaq Ahmad Kaw and Aijaz Ahmad Banday, Central Asia: Introspection, "Centre of Central Asian Studies", University of Kashmir, 2006, p.340.

[3]. Mushtaq A Kaw, Central Asia in Retrospect and Prospect, "Centre of Central Asian Studies", Kashmir University, 2010, p.265.

[4]. Madhavan K. Palat and Anara Tabyshalieva Co-Editors, History of Civilization of Central Asia, Vol. VI, UNESCO Publishing, 2005, p.529.

[5]. Massell Gregor, The Surrogate Proletariat: Muslim Women and revolutionary strategies in Soviet Central Asia 1919-1929, Princeton University Press, 1974, p.10.

[6]. Mary Buckley, Post Soviet Women; From Baltic to Central Asia, Cambridge University Press, 1997, p. 265.

[7]. Harris Colette, Women of the Sedentary Population of Russian Turkistan through the eyes of Western Travellers, "Central Asian Survey", Vol. 15, No.1,1996, p.84

[8]. Darakshan Abdullah, Role and Status of Women in Turkistan, Emergence of Central Asia Perspective, Gulshan Majeed (ed), Srinagar, 2005, p.206.

[9]. Schuyler Eggene, Turkistan, notes of journey in Russian Turkistan, Khokand, Bukhara and Kuldja, Vol.1, Charles Scribner, New York, 1876, p.144-147

[10]. Lawrence Krader, Peoples of Central Asia, Indiana University Bloomington, Mounton and Co, 1963, pp.141- 146.

[11]. The levirate is the practice of marriage of a widow with the deceased husband's brother, usually the younger brother.

[12]. Wheeler Jeoffery, The Modern History of Soviet Central Asia, Weidenfeld and Nicolson, London, 1964, p.41.

[13]. Harris Colette, Women of the Sedentary Population of Russian Turkistan through the eyes of Western Travellers, "Central Asian Survey", Vol. 15, No.1,1996, p.91.

[14]. Meakin Anetic, In Russian Turkistan, Geogre Allen,. London, 1993, pp.100-102,146, 212.

[15]. Saud Joseph, Encyclopedia of Women and Islamic Cultures, Economics, Education, Mobility and Space, Brill Leiden-Boston, 2007, Vol. IV, p.333.

[16]. Habiba Fathi, Gender, Islam and Social Change, "Central Asian Survey", September 2006, Vol. 25, No. 1, p.308.

[17]. History of Civilization of Central Asia, Vol.VI, Co-Editors Madhavan K. Palat and Anara Tabyshalieva, UNESCO Publishing, 2005 , p.529.

[18]. Khalid Adeeb, The Politics of Muslim Cultural Reform: Jadidism in Central Asia, University of Calfornia Press Ltd, London, 1998, p. 225 .

[19]. Nancy Lubin, Women in Soviet Central Asia: Progress and Contradictions, "Soviet Studies",Vol. XXXIII,No.2,April 1981, p.182.

[20]. Mary Buckley, Post Soviet Women; From Baltic to Central Asia, Cambridge University Press, 1997, p.268.

[21]. Habiba Fathi, Otines the Unknown women Clerics of Central Asian Islam, Central Asian Survey, 1997, No. 16(1), p.28

[22]. Mary Buckley, Post Soviet Women; From Baltic to Central Asia, Cambridge University Press, 1997, pp.268-269.

[23]. Aminova. R.Kh , The October Revolution and Women's Liberation in Uzbekistan, Central Department of Oriental Literature," Nauka Publishing House, 1997, pp.12-15.

[24]. History of Civilization of Central Asia, Vol.VI, Co-Editors Madhavan K. Palat and Anara Tabyshalieva, UNESCO Publishing, 2005, Op.Cit., p.530.

[25]. Mary Buckley, Post Soviet Women; From Baltic to Central Asia, Cambridge University Press, 1997, p.269.

[26]. Fannina W.Halle, Women in the Soviet East, London, 1938, p.142.

[27]. Aminova. R.Kh The October Revolution and Women's Liberation in Uzbekistan, Central Department of Oriental Literature," Nauka Publishing House, 1997, pp 95-121.

[28]. Mary Buckley, Post Soviet Women; From Baltic to Central Asia, Cambridge University Press, 1997 , p.270.

[29]. Ajay Patnaik, Perestroika and Women Labour Force in Soviet Central Asia, New Literature, New Delhi, January, 1989 , pp.23-24.

[30]. H.Kent Geiger, The Family in Soviet Russia, Havard University Press, 1970, p.130.

[31]. Aminova. R.Kh The October Revolution and Women's Liberation in Uzbekistan, Central Department of Oriental Literature," Nauka Publishing House, 1997, R. Kh pp.17-18.

[32]. Mary Buckley, Post Soviet Women; From Baltic to Central Asia, Cambridge University Press, 1997, p 273.

[33]. Chenoy Anuradha M, Soviet and Post-Soviet Perception of Central Asian Women, in "Women in Asia: Work, Culture and Politics in South and Central Asia", edited by Ranabir Sammaddar, Vikas Publishing House Pvt. Ltd., 1997, p.127.

[34]. Chenoy Anuradha M, Soviet and Post-Soviet Perception of Central Asian Women, in "Women in Asia: Work, Culture and Politics in South and Central Asia", edited by Ranabir Sammaddar, Vikas Publishing House Pvt. Ltd., 1997 p.274.

[35]. Economic and Social Commission For Asia and the Pacific, Studies on Women in Development, Promoting Women's Rights as Human Rights, United Nations, New York, 1999, p.127.

[36]. Ajay Patnaik, Socio-cultural changes in post-Soviet Central Asia, in Vohra, N.N., Culture, Society and Political in Central Asia and India, Delhi: Shipra Publications, 1999, p. 207.

[37]. Pradhan Sanjay and Dutta Geetanjali, Status of Women in Independent Uzbekistan, Asian Studies, Vol. XXIV, January, 2006, No,1, p. 110

[38]. Renate Weber and Nicole Watson( Chief Editors), Women 2000, An Investigation into the Status of Women's rights in Central and South-Eastern Europe and the Newly Independent States, International Helsinki Federation for Human Rights, 2000, p.498.

[39]. Timur Dadabaev, Post Soviet Realities of Society in Uzbekistan, "Central Asian Survey", Routeldge, Vol. 23, No. 2, June, p.156.

[40]. Vasundara mohan,Status of Women in Central Asia:A Study in Uzbeksitan,Contemporary Central Asia,Vol.6,No.2,2002, p 50

[41]. Marfua Tokhtakhodjaeva, , Between the Slogans of Communism and the Laws of Islam: The Women in Uzbekistan, Lahore, Pakistan, 1995, p.96.

[42]. Economic and Social Commission For Asia and the Pacific Studies on Women in Development, Promoting Women's Rights as Human Rights, United Nations, New York, 1999, p.129.

[43]. Feride Ascar and Ayse Gunes Ayta, Gender and Identity Construction; Women in Central Asia, The Caucasus and Turkey, Brill, Netherlands, 2000, p.297.

[44]. Sacrificing Women to Save the Family, "Domestic Violence In Uzbekistan”, Human Rights Watch, Vol. 13. No .4 (D), p.13. Ibid. 76.

[45]. p.271 
[46]. Marfua Tokhtakhodjaeva, Between the Slogans of Communism and the Laws of Islam: The Women in Uzbekistan, Lahore, Pakistan, 1995 p. 245.

[47]. Wendy Mee, Country Briefing Paper, Women in the Republic of Uzbekistan, ADB, February, 2011, p.19.

[48]. Mary Buckley, Post Soviet Women; From Baltic to Central Asia, Cambridge University Press, 1997, p.288.

[49]. Wendy Mee, Country Briefing Paper, Women in the Republic of Uzbekistan, ADB, February, $2011, \quad$ p.32.

[50]. Chenoy, A Making of New Russia, New Delhi, 2002,p p.232-233

[51]. Pradhan Sunjay Kumar and Dutta Geetanjali, "Status of women in Independent Uzbekistan", Asian Studies, VO1 XXIV, JanuaryDecember 2006, No. 1 and 2, p-113.

[52]. Suad Joseph, Encyclopedia of Women and Islamic Cultures, Vol. IV, Brill-Leiden-Boston, 2007, p. 161-162

[53]. Renate Weber and Nicole Watson( Chief Editors), Women 2000, An Investigation into the Status of Women's rights in Central and South-Eastern Europe and the Newly Independent States, International Helsinki Federation for Human Rights, 2000 , p.497.

[54]. Wendy Mee, Country Briefing Paper, Women in the Republic of Uzbekistan, ADB, February, 2011 ,p.20.

[55]. Christa Hammerle and Margareth Lanzinger, Gender Politics In Central Asia: Historical perspective and current living conditions of woman, Bonlav Verlag, 2008, p.118.

[56]. Renate Weber and Nicole Watson( Chief Editors), Women 2000, An Investigation into the Status of Women's rights in Central and South-Eastern Europe and the Newly Independent States, International Helsinki Federation for Human Rights, 2000, `pp.501-502.

[57]. Feride Ascar and Ayse Gunes Ayta, Gender and Identity Construction; Women in Central Asia, The Caucasus and Turkey, Brill, Netherlands, 2000, p.296.

[58]. Renate Weber and Nicole Watson( Chief Editors), Women 2000, An Investigation into the Status of Women's rights in Central and South-Eastern Europe and the Newly Independent States, International Helsinki Federation for Human Rights, 2000 , p.502.

[59]. Wendy Mee, Country Briefing Paper, Women in the Republic of Uzbekistan, ADB, February, 2011, p.18.

[60]. Renate Weber and Nicole Watson( Chief Editors), Women 2000, An Investigation into the Status of Women's rights in Central and South-Eastern Europe and the Newly Independent States, International Helsinki Federation for Human Rights, 2000 , p.502.

[61]. Christa Hammerle and Margareth Lanzinger, Gender Politics In Central Asia: Historical perspective and current living conditions of woman, Bonlav Verlag, 2008 p.130.

[62]. Saud Joseph, Encyclopedia of Women and Islamic Cultures, Economics, Education ,Mobility and Space, ,Brill Leiden-Boston, 2007, Vol. IV, p.374.

[63]. Status o fwomen in .Pradhan Sanjay and Dutta Geetanjali, Status of Women in Independent Uzbekistan, Asian Studies, Vol. XXIV, January, 2006, No,1,p113

[64]. Mr. Djamoliddin Fazylov and Mrs. Galina Smirnova, The Development of Education, "National Report of Uzbekistan", 26 September 2008, p.10.

[65]. Wendy Mee, Country Briefing Paper, Women in the Republic of Uzbekistan, ADB, February, 2011,p.11-12. 